RESEARCH PAPER

\title{
"Asia is now the priority target for the world anti-tobacco movement": attempts by the tobacco industry to undermine the Asian anti-smoking movement
}

\author{
J Knight, S Chapman
}

Tobacco Control 2004;13(Suppl II):ii30-ii36. doi: 10.1136/tc.2004.009159

See end of article for authors' affiliations

Correspondence to: Dr Jennifer Knight, School of Public Health, Room 129A, Edward Ford Building (A27), University of Sydney, NSW 2006 Australia; knighti@health. usyd.edu.au

\begin{abstract}
Study objective: To identify and examine the strategies utilised by multinational tobacco companies to undermine and discredit key anti-tobacco activists and organisations in the Asian region.

Method: A series of case studies drawing upon material gathered through systematic reviews of internal tobacco industry documents.

Date sources: Tobacco industry documents made public as part of the settlement of the Minnesota Tobacco Trial and the Master Settlement Agreement.

Results: The industry sought to identify, monitor, and isolate key individuals and organisations. The way industry went about fulfilling this mandate in the Asian region is discussed. Industry targetted individuals and agencies along with the region's primary anti-smoking coalition.

Conclusions: Attack by multinational tobacco companies is a virtual quid pro quo for any individual or agency seriously challenging industry practices and policies. Understanding their tactics allows anticipatory strategies to be developed to minimise the effectiveness of these attacks.
\end{abstract}

n 1992 a tobacco industry critic suggested people become involved in tobacco control for "the self satisfaction to be socially recognised as modern crusaders of other people's health"1 as well as "the intoxicating feeling of possessing some political influence or power". ${ }^{1}$ For all his cynicism, the critic, P Donck of the Centre d'Information et de Documentation (CIDT), warned his industry audience that tobacco control had created "a new wall of Berlin and we [the industry] are locked in".'

The tobacco industry has always been acutely aware of those it dubs as "antis". Internal documents demonstrate the occasionally thorough understanding the industry had of the origins and development of the anti-smoking movement, ${ }^{1-5}$ but also often its deep naivety about global tobacco control.

It knew, for example, that tobacco control was multi-tiered occurring at the international, regional, national, and grassroots levels. The functions of the first three tiers of the structure were spelt out simplistically by Donck: agencies at the global level concentrated on programmes and policy; regional level agencies were responsible for coordination and lobbying, while the emphasis of agencies at the national level was on lobbying. ${ }^{1}$ In 1990, with the release of the American Cancer Society convened global plan, "Trade for Life", ${ }^{6}$ the approach shifted "the fight" to the regional and local front. ${ }^{1}$ The regional groups were to be managed by a "small and committed group of individuals" ${ }^{\prime 2}$ amusingly dubbed by the industry as the "golden circle". ${ }^{12}$

The industry was also aware of their opponents' supporting infrastructure which included the international World Conferences on Smoking or Health ("why do they have such a conference-self indulgence, self congratulation..." ${ }^{\prime 7}$ ), the international journal Tobacco Control (an "unlimited source of information which can serve to implement our own strategies" as "all their arguments, strategies, tactics, actions are openly described in detail" ${ }^{\prime 1}$ ), and the internet advocacy network, GLOBALink.

The industry feared its opponents had "the support of politicians and academics"1 and as a result, industry was "under attack on all fronts and on all issues". ${ }^{1}$ As PMI (Philip
Morris International) admitted in 1986 "their combined influence is formidable, firstly in scientific circles and latterly [sic] in the political arena". ${ }^{8}$

In 1989 Philip Morris Asia's Corporate Plan for 1990-92 noted that, in the previous year, regional anti-smoking activity in Asia had "increased dramatically" and was expected to escalate during the Plan period. ${ }^{9}$ It concluded that "Asia has become a focus of the global anti-smoking movement". ${ }^{9}$ Hill and Knowlton (one of the advertising agencies used by Philip Morris (PM) in Asia) noted in 1993 that "the anti-smoking lobby has made significant gains in all countries throughout the region... with countries like Singapore, Malaysia and Thailand following anti-smoking developments in Canada and Europe ${ }^{\prime \prime}{ }^{10}$ Newsweek acknowledged the role of the tobacco control movement when, in 1994, an article described these "crusaders" as Marlboro's "Asian nightmare". ${ }^{11}$

Tobacco control groups also were perceived by the industry as exerting significant influence at the national level. In less than a decade Hong Kong (HK), for example, went from a country where in 1983 "the anti-smoking lobby... [was] largely anonymous, unidentifiable, entirely unrepresentative and unaccountable"12 and "the anti-smoking campaign appears to lack real seriousness and long-term viability"13 to being a country with "a highly active and sophisticated anti-smoking network". ${ }^{14}$ In Thailand, British American Tobacco (BAT) acknowledged in 1993 that "there is no question that Thailand has a very strong anti-cigarette movement which if left unchallenged will have long term impact on the industry". ${ }^{15}$

This paper examines the Asian region and, through a series of case studies, reviews attempts by multinational tobacco companies operating in Asia to counter and undermine

Abbreviations: APACT, Asia Pacific Association of Control Tobacco; ATC, Asian Tobacco Council; BAT, British American Tobacco; COSH, Council on Smoking and Health; ETS, environmental tobacco smoke; HK, Hong Kong; ICOSI, International Council on Smoking Issues; PM, Philip Morris; TIHK, Tobacco Institute of Hong Kong; TIOJ, Tobacco Institute of Japan 
activities of tobacco control organisations (both government and non-government) and individuals.

\section{METHODS}

This study is based upon material contained in recently released internal tobacco industry documents. Key words utilised in searches of both tobacco industry and nonindustry websites included "Asia", "antis", "APACT" (Asia Pacific Association of Control Tobacco), "COSH" (Council on Smoking and Health), "tobacco control", "anti-tobacco network", "antismoking movement" as well as the names of key individuals identified in relevant documents. Although all relevant tobacco industry websites were searched, the Philip Morris (www.pmdocs.com) and Tobacco Documents Online (http://tobaccodocuments.org) websites provided most of the relevant documents. In total, 128 pertinent documents were retrieved and used as the basis for the series of qualitative case studies which make up this paper. Further details of the paper's methodology can be found at http://tobacco.health. usyd.edu.au/site/gateway/docs/pdf/ Regional.pdf.

\section{RESULTS}

The tobacco control movement and the international tobacco industry have long sought to counteract each others' activities. As early as 1979 when the International Council on Smoking Issues (ICOSI) hosted the "Countermeasures Development Program" in Zurich ${ }^{16}$ the tobacco industry has been interested in the work of those who oppose it. Over the following two decades, the industry built up a comprehensive dossier on its opponents including those in the Asian region. During this time they sought to know the anti-smoking movement's strategies and objectives. PM, for example, was clear on the tobacco control's objectives and strategies identifying their opponents' strengths ("easy access-government and media") and vulnerabilities ("strident"). ${ }^{17}$

The industry's concern is evident in the number of briefings prepared and speeches delivered on the issue (table 1). Some of these papers had a global focus, with all

\begin{tabular}{|c|c|c|c|}
\hline Date & Format & Focus & Publication \\
\hline 1981 & Notes & Global & $\begin{array}{l}\text { Overview of anti-smoking groups activities } \\
\text { and the tobacco industry's response }{ }^{19}\end{array}$ \\
\hline 1982 & Paper & Global & $\begin{array}{l}\text { Report on the strategy of activists and how } \\
\text { to respond to that strategy }{ }^{4}\end{array}$ \\
\hline 1983 & Paper & HK & $\begin{array}{l}\text { Update on anti-smoking campaign and } \\
\text { Consumer Council-programmes and } \\
\text { personalities }\end{array}$ \\
\hline 1983 & Paper & Asia & Smoking control in south-east $\mathrm{Asia}^{21}$ \\
\hline 1983 & Paper & $\mathrm{HK}$ & Key government personalities in tobacco ${ }^{13}$ \\
\hline 1989 & Paper & Asia & $\begin{array}{l}\text { Philip Morris Asia: corporate affairs plan, } \\
1990-92^{\circ}\end{array}$ \\
\hline 1992 & Paper & Global & The activist movement ${ }^{22}$ \\
\hline 1992 & Speech & Global & Our opponents' \\
\hline 1992 & Paper & Taiwan & Strategy of the antis for Taiwan ${ }^{23}$ \\
\hline 1992 & Paper & Global & Changes in the activist movement ${ }^{24}$ \\
\hline 1993 & Paper & Asia & $\mathrm{APACT}^{25}$ \\
\hline 1993 & Paper & Global & $\begin{array}{l}\text { Global regulatory network: "we will be } \\
\text { legal everywhere we do business"s }\end{array}$ \\
\hline 1993 & Paper & Asia & Notes on WHO anti-tobacco programme $\mathrm{e}^{26}$ \\
\hline 1993 & Speech & Glob & Anti-tobacco strategies ${ }^{2}$ \\
\hline 1993 & Paper & Global & Key area paper: corporate affairs ${ }^{18}$ \\
\hline ] & Pape & Global & $\begin{array}{l}\text { Background to the structure and operations } \\
\text { of the activist movement }\end{array}$ \\
\hline 1995 & Paper & Asia & $\begin{array}{l}\text { Corporate affairs-regional overview: } \\
\text { Asia" }\end{array}$ \\
\hline
\end{tabular}

APACT, Asia Pacific Association for Control of Tobacco; HK, Hong Kong, WHO, World Health Organization but two ${ }^{418}$ including detailed briefings on the anti-smoking movement in Asia.

The International Tobacco Information Center's (INFOTAB) "Guide for dealing with anti-tobacco pressure groups" 27 identified 10 "danger signals" or key indicators as part of a "early warning alert system" of "approaching attacks" by pressure groups. ${ }^{27}$ The publication encouraged the industry to identify those indicators existing in their country and to "be alert to future attacks". ${ }^{27}$ The indicators and their occurrence in the Asian region are found in table 2 .

All of the "danger signals" were present in the Asian region, prompting PM's John Dollisson, who at the time was based in HK, to announce in June 1989 that "Asia is now the priority target for the world anti-tobacco movement". ${ }^{33}$

The INFOTAB guide and other industry documents identified a number of strategies to counter the work of the anti-smoking movement. The industry in Asia appears to have concentrated its energies and resources on four specific strategies.

\section{"Monitor the presence of known activists critical"}

The industry monitored anti-smoking groups in a number of ways. They compiled a series of directories between 1986 and 1999. ${ }^{34-39}$ The industry also monitored resources produced and distributed by their opponents. On at least two occasions PM distributed WHO's "Action Plan on Tobacco or Health for 1995-1999" to its staff. PM considered the plan to be "essential reading" ${ }^{\prime \prime 0}$ and "always interesting to see how the opposition crafts its legislative language and sets its priorities". ${ }^{41}$

Industry also monitored the finances available to tobacco control. A country-by-country breakdown for the Asian region was prepared by PM (table 3). At that time, PM noted that its staffing (cited at 16) and budget fell far short of their opponent's staffing levels and funding of \$7.45million. ${ }^{17}$

The accuracy of these data is highly dubious given that it was widely recognised there were "few full-time people working on tobacco control in the Asia-Pacific region". ${ }^{42}$ Further, industry does not appear to acknowledge the seemingly open chequebook it had access to when necessary. When seeking to influence governments of the region as well as the general public on the issue of environmental tobacco smoke (ETS), for example, PM was "willing to commit millions of US\$ to the project". ${ }^{43}$ In HK industry spent \$3-4 million annually in the early 1980s on advertising. ${ }^{13}$ This was in sharp contrast to the government's anti-smoking budget of $\$ 400000$ considered by industry to be "relatively small". ${ }^{13}$

\section{"We must attack the anti-smoking... Zealots"}

Having identified and monitored known tobacco control groups, the industry then sought to "carefully target our opponents" 45 whom it considered to be "particularly driven by the demons of overzealous moral righteousness". ${ }^{46}$ Their approach was to "attack" the "downright zealotry and extremism of our opponents" ${ }^{\prime 46}$ :

\section{"We need to develop programs that expose the anti- smoking activists for what they are - shrill and extreme. If we are successful in revealing to the public the zealots, the blind crusaders for a cause, this will mitigate pressure on social acceptability." 46}

The industry has long recognised the role played by medical practitioners in the area of tobacco control. As early as 1973 the HK based industry recognised that:

"the medical authorities are the strongest single influence
on government restrictive action in the field of smoking 
Table 2 Key indicators and their occurrence in the Asian Region

\begin{tabular}{|c|c|}
\hline Key indicators ${ }^{27}$ & Occurrence of indicators in Asia \\
\hline $\begin{array}{l}\text { The presence of a World Health } \\
\text { Organization (WHO) regional } \\
\text { office or sub-office }\end{array}$ & $\begin{array}{l}\text { WHO regional office based in Manila, Philippines: "the WHO } \\
\text { regional offices... see smoking control as an important component of } \\
\text { their long-term efforts to hold down health costs in developing } \\
\text { countries" }\end{array}$ \\
\hline $\begin{array}{l}\text { The presence of an International } \\
\text { Organisation for Consumer Unions } \\
\text { (IOCU) office }\end{array}$ & IOCU Asia Pacific Regional Office based in Penang, Malaysia \\
\hline $\begin{array}{l}\text { The conduct of a regional } \\
\text { workshop of activists }\end{array}$ & $\begin{array}{l}\text { For example, 3rd Working Group on Tobacco or Health held in the } \\
\text { Philippines (April 1994) }\end{array}$ \\
\hline $\begin{array}{l}\text { The presence of activist group } \\
\text { or key individuals }\end{array}$ & $\begin{array}{l}\text { Activists groups: for example, "Countries including China, Malaysia, } \\
\text { Hong Kong, Korean Republic and Thailand have established national } \\
\text { coordinating organisations on tobacco control. Singapore, Indonesia } \\
\text { and the Philippines have active health societies"29 } \\
\text { Key individuals: for example, Judith Mackay, Tony Hedley and TH Lam } \\
\text { (HK), Hatai Chitanondh, Prakit Vateesatokit (Thailand), Anwar Fazal } \\
\text { (Malaysia), Ted Chen (Taiwan) }\end{array}$ \\
\hline $\begin{array}{l}\text { The setting up of a non-smokers' } \\
\text { rights association }\end{array}$ & For example, Japan ${ }^{29}$ \\
\hline $\begin{array}{l}\text { The starting up of a tobacco } \\
\text { control coalition }\end{array}$ & $\begin{array}{l}\text { The Asia Pacific Association for Control of Tobacco (APACT) was } \\
\text { formed in Taiwan in } 1993\end{array}$ \\
\hline $\begin{array}{l}\text { The availability of existing or } \\
\text { enabling legislation }\end{array}$ & $\begin{array}{l}\text { "By } 199533 \text { of } 35 \text { Asian countries had tobacco control laws on their } \\
\text { books" }\end{array}$ \\
\hline $\begin{array}{l}\text { The publication by the antis of a } \\
\text { discussion document proposing } \\
\text { draft legislation }\end{array}$ & $\begin{array}{l}\text { For example, "A suggested model of a tobacco products control } \\
\text { law" }\end{array}$ \\
\hline $\begin{array}{l}\text { The publication of an IOCU backed } \\
\text { industry attack }\end{array}$ & $\begin{array}{l}\text { For example, "The lung goodbye: a manual of tactics for } \\
\text { counteracting the tobacco industry in the } 1980 \mathrm{~s}^{\prime \prime 32}\end{array}$ \\
\hline The holding of WHO World & For example, HK, Indonesia, Korea, Malaysia, PRC, Singapore, \\
\hline No-Tobacco Day & Philippines and Thailand observed No-tobacco Day in 1999 \\
\hline
\end{tabular}

and health... the views of informed medical authorities will affect the future of the industry. An important objective of the industry must therefore be to obtain the goodwill of influential medical opinion..."47

Industry was not always successful in obtaining such "goodwill". Writing within the Thai context Chantornvong and McCargo have noted the "success" of anti-tobacco campaigns led by medical doctors. ${ }^{48}$ They observe that in Thailand "many prominent" 48 doctors presented themselves as government officials, academics and/or NGO activists. These "leading doctors" ${ }^{48}$ were able to command respect and support from a wide range of organisations and social groups. ${ }^{48}$ The observation was not only applicable to Thailand. In HK, for example, a number of doctors were also prominent tobacco control activists. Most notable of these were Dr Tony Hedley, Dr TH Lam, and Dr Judith Mackay (all of whom played very significant roles in the administration and success of the Council on Smoking and Health ( $\mathrm{COSH})$ ).

Table 3 Comparison of resources: Philip Morris versus tobacco control"

\begin{tabular}{|c|c|c|c|c|}
\hline \multirow[b]{2}{*}{ Market } & \multirow{2}{*}{$\begin{array}{l}\text { PM budget } \\
\text { US\$ ('000) }\end{array}$} & \multirow{2}{*}{$\begin{array}{l}\text { Tobacco control } \\
\text { budget US\$ ('000) }\end{array}$} & \multicolumn{2}{|c|}{ Antis staff } \\
\hline & & & $F / T$ & $P / T$ \\
\hline Korea & 537 & 20 & 11 & $10^{*}$ \\
\hline PRC & 400 & 450 & 8 & $6^{*}$ \\
\hline Taiwan & 445 & 1250 & $15^{*}$ & $100 *$ \\
\hline $\mathrm{HK}$ & 250 & 1760 & $6+$ & $5^{*}$ \\
\hline Philippines & 333 & 1583 & $25 t$ & $236^{*}$ \\
\hline Malaysia & 548 & & & \\
\hline Indonesia & 80 & 200 & & \\
\hline Singapore & 360 & 1623 & $9+$ & $15-20^{*}$ \\
\hline Thailand & & 440 & & \\
\hline Pakistan & & 125 & & \\
\hline
\end{tabular}

*Private; tgovernment.

$F / T$, full time; $P / T$, part time.
Mackay was particularly targeted by the industry. A 1989 public relations proposal prepared for the Tobacco Institute of Hong Kong (TIHK), for example, suggested industry "act where possible to influence the attitudes to Dr Judith Mackay and her questionable platforms". ${ }^{49}$ They referred to Mackay as "Hong Kong's version of C. Everett Koop", , "the noisiest and the most difficult [of HK based antis]", 20 "a particularly painful thorn in their [multinational tobacco companies] side", 30 "most outspoken and difficult... a staunch social activist and very simplistic"13 and one of three "hardliners". ${ }^{13}$ They occasionally acknowledged her strengths: "Mackay will... do her usual expert job". ${ }^{23}$

\section{"We shall precisely...isolate and contest key...organizations" 45}

In addition to trying to discredit individuals who opposed them, the industry also attacked tobacco control activist groups. The rationale behind this strategy was spelt out by PM:

"if we can cool their [anti-smoking groups'] zeal just a bit, not only might smoking as a subject become less of an issue but also smokers might begin to feel less embattled" ${ }^{44}$

In Asia, the industry specifically targeted COSH, one of the region's most active anti-smoking government agencies. COSH was established by the HK government in 1987 with a mandate to introduce a range of tobacco control measures as well as develop education programmes and conduct research. ${ }^{51}$ From its inception, the industry carefully monitored $\mathrm{COSH}$ aiming to "oppose the role of $\mathrm{COSH}$ as an executive decision making body". ${ }^{52}$ Within months of the establishment of COSH, the industry had identified two instances in which it had "overstepped its bounds". ${ }^{52}$ When COSH's first major policy initiative was released in 1989 the industry's response was clear: "we are fighting the $\mathrm{COSH}$ proposals". ${ }^{33}$ 
The primary strategy employed by the industry against $\mathrm{COSH}$ was to discredit its work in the eyes of both the government and the general public. It was relentless in this task. It responded to every initiative of the agency: it countered $\mathrm{COSH}$ surveys with industry generated surveys (see for example ${ }^{53}$ ); it made submissions to the government in response to $\mathrm{COSH}$ publications ${ }^{545}$; it gloated over the fate of COSH ("apparently COSH is falling apart"156). COSH's recommendations were, according to the industry, "highly emotive; based on medical and scientific claims which are not proven"55; its attitude a "confrontational mentality with the obvious motive of isolating the industry from the community". ${ }^{54}$

The industry also sought to discredit $\mathrm{COSH}$ in the eyes of the general public. In 1989, for example, the TIHK engaged in an extensive publicity campaign which included talks at Rotary Clubs, press releases, press conferences, letters to the editor, and a mailing campaign of 1500 letters as well as a survey on public opinion. ${ }^{57}$

\section{"Monitor the formation of any anti-smoking coalition" 27}

The industry sought to minimise the impact of anti-smoking coalitions. The primary coalition in the Asian region was APACT and it is this association which the industry primarily targeted. Founded in 1989 initially to address market access and trade issues it quickly became an umbrella group bringing together all national tobacco control interests in the region. ${ }^{3}$

The formation of a regional body brought an entirely new dimension into the equation which the industry had to address:

\begin{abstract}
"We had better pay attention to it [APACT]. It is paying attention to us... APACT will act in an increasingly coordinated manner throughout the Asia-Pacific region on a wide variety of anti-smoking activities and will become more skilful as they gain experience ${ }^{\prime \prime} .{ }^{25}$
\end{abstract}

and

\begin{abstract}
"In the past we contended with anti-smoking organisations on a country-by-country basis... the new organisation adds a regional quality to the mix which means our foes will become increasingly sophisticated and well coordinated. The challenge will be much more serious" ${ }^{25}$
\end{abstract}

Within six months of its formation PM was clear on its objective toward APACT: "our objective is to limit their ability to influence public policy". ${ }^{9}$ The industry went about this in a number of ways. It, for example, established a regional industry association, the Asian Tobacco Council (ATC) which was based in HK. The ATC's statement of purpose included:

\footnotetext{
"to monitor regional anti-smoking groups, communicate information concerning the structure and activities of such groups to industry representatives and develop and coordinate regional action plans to address anti-smoking initiatives" ${ }^{\prime \prime}$.
}

The ATC's mandate was simple: "monitor the activities of APACT and develop strategies to counter their activities with special attention to ensuring balanced coverage in the media". " The job description for the position of ATC managing director clearly articulated the first responsibility to be "to monitor and advise...an industry response to regional anti-tobacco organisations". ${ }^{59}$
A 1991 ATC public affairs conference placed the issue of antis as number one on the agenda. Questions to be considered during the course of the conference included:

\begin{abstract}
"What is the opposition up to, and what do we consider are its priorities? How well do we know what the opposition thinking is... How can we better monitor opposition activity? How can we identify and get to know more about some of the more committed activists? How can we get a better handle on opposition lobbying? ...what more can we do to balance the unremitting and emotionally geared anti-tobacco crusading? ...antitobacco momentum is increasing-and with emphasis on our region." 60
\end{abstract}

In addition to the work of the ATC, industry sought to impact upon as many APACT strategies and activities as possible.

\section{Countering lobbying activities}

In the lead up to bilateral trade talks between Taiwan and the USA in 1992, APACT (along with the Taiwanese based Tung Foundation) undertook an extensive lobbying campaign against the proposed trade deal which included full page advertisements in major US newspapers, demonstrations in Taipei, and a local media campaign. ${ }^{23}$ The objectives of industry's response were to:

"blunt the media and lobbying campaign and shore up USG [United States Government] support for modifying the Bill; [and] rebut the antis publicly and privately in order to maintain industry credibility, defend exports, and keep tobacco issues in proper perspective" ${ }^{\prime 23}$

Industry counter-strategies included the development of "short but meaty responses" to anticipated statements/ allegations from the antis; counter-attack themes; establishment of an "industry War Room in Taipei" to act as an information and coordination centre; and advertisements to counter the Washington Post advertisement. ${ }^{23}$ A press release urged both governments to "not be swayed by emotion and the extremism of lobbying groups" ${ }^{61}$

\section{Conferences}

The industry monitored APACT conferences in the region up to at least 2001. Examples of the industry's activities and counter-measures are summarised in table 4.

\begin{tabular}{|c|c|c|c|}
\hline No & Date & Country & $\begin{array}{l}\text { Industry's response: activities and counter- } \\
\text { measures }\end{array}$ \\
\hline $1 \mathrm{st}$ & 1989 & Taiwan & $\begin{array}{l}\text { Press release by US Cigarette Export } \\
\text { Association: "allegations about US cigarette } \\
\text { exports made at the recently concluded [APACT } \\
\text { Conference] are biased and often without } \\
\text { factual foundation" }\end{array}$ \\
\hline 2nd & 1991 & Korea & $\begin{array}{l}\text { Media briefings by industry consultant Philip } \\
\text { Witorsch, George Washington Medical Centre. } \\
\text { Briefings were "to counter allegations made at } \\
\text { the APACT Conference and specially refute Dr } \\
\text { Hirayama's data on the subject of ETS" }\end{array}$ \\
\hline $3 r d$ & 1993 & Japan & $\begin{array}{l}\text { Media conference by TIOJ President }{ }^{70} \text {; detailed } \\
\text { strategy memo }{ }^{71} \text {; Action Plan for APACT }{ }^{4-66}\end{array}$ \\
\hline 4th & 1995 & Thailand & $\begin{array}{l}\text { Three extensive reports prepared by } \\
\text { industry }\end{array}$ \\
\hline
\end{tabular}


The industry appears to have been most organised for the 1993 APACT conference held in Japan. Two approaches were utilised. An international symposium on ETS was held in Tokyo in April, several months before the APACT conference. The timing was not coincidental. Covington and Burling's John Rupp noted to Dr Sharon Boyse of BAT, "the Tokyo symposium is the centerpiece of the industry's efforts to counter the APACT meeting". ${ }^{62}$ Similarly PM noted that "the symposium to be held in Tokyo in April is significant; first because of the impact Japan has on the region and the rest of the world and in addition, to pre-empt the meeting of the APACT in Tokyo shortly thereafter" ${ }^{63}$

The industry monitored the conference with a degree of precision not seen before. The Tobacco Institute of Japan (TIOJ) was responsible for developing an "Action Plan for APACT" $^{\prime 64}$ which was issued to all participating tobacco companies. The very detailed plan itemised "counter measures" before and during the conference as well as tips on handling the media. ${ }^{64}$ Attached documents requested that each company would nominate a monitor ${ }^{65}$ and a monitoring programme and training schedule were provided. ${ }^{66}$

PM also claimed to have been able to deter media reporting of an APACT meeting in 1997:

\section{"When the Asia Pacific Association for the Control of Tobacco held its triennual meeting in Bangkok, we monitored the event, and provided timely intelligence on what was being discussed. We were also able, discreetly, to manage much of the media reporting of the Conference."}

\section{DISCUSSION}

Asia was a quandary for multinational tobacco companies. On one hand it was "a market of great promise for international tobacco companies" ${ }^{\prime 30}$ while on the other growth was "being challenged at every step by increasingly aggressive and self-assured tobacco control campaigners". ${ }^{30}$

The work of these "aggressive" campaigners had two characteristics. First, the impact of their work was substantial. Individuals and organisations, both government and non-government, shaped policy, drafted legislation, educated the public, lobbied decision makers, informed and worked the media. Their work impacted upon national tax schedules, advertising in all forms of media, sponsorship of sporting and cultural events, and indoor air quality.

Second, the influence of their work was widespread. By 1996, 33 of 35 countries in the region had, according to Mackay, adopted some form of anti-smoking restrictions. ${ }^{30}$

While the work of those campaigning against the tobacco industry may have been substantial and widespread, for a number of individuals, it came at a cost. In pursuing a goal of improved public health, many activists did so at the risk of ongoing and sustained personal derision and defamation. Yet, they persisted and their contribution is acknowledged and recognised.

Industry's response to the work of tobacco control was intense. The degree of this intensity is exemplified in the imagery consistently used. In studying industry documents it is hard not to be struck by the consistent use of warfare imagery: "the anti-tobacco brigade are marching ever forward"78; "we mustn't forget that a state of war does exist" ${ }^{\prime 16}$; "antismoking activism [has] the sanctity of an international crusade, a Holy War"79; and "the battle will be fought in the media and in the halls of government". ${ }^{25}$ John Dollisson provided some of the most colourful imagery when presenting at a PMI conference:
"We are engaged in a 'war' against our industry. And I use the word 'war' advisedly. The kind of war we are engaged in is a guerrilla war... the most difficult kind of all... the damage they inflict at any particular time is limited but, cumulatively, they have the capacity to inflict what could add up to a fatal blow. They have positioned their snipers and laid their minefields. ${ }^{\prime 80}$

\section{Conclusion}

The tobacco industry has a well documented history of meddling in the affairs of international bodies (for example, $\mathrm{WHO}^{81}$ ) and events (for example, World Conferences on Smoking or Health ${ }^{82}$ ). The interference they sought to exert was not limited to the international arena.

This study shows that the tobacco industry had the resources and vested interest to target key anti-tobacco individuals, organisations, and coalitions within the Asian region. Awareness of industry's strategies and tactics is a valuable tool in combating industry strategy to undermine tobacco control efforts. Such an understanding may go some way to diffusing the effectiveness of the attacks. It is important for both regional and the worldwide public health communities to be aware of the numerous ways in which the tobacco industry will work against their efforts.

Industry attacked high profile individuals actively involved in tobacco control. It is likely multinational tobacco companies will continue to harass and discredit the work and credibility of those seriously challenging industry practices: tobacco control activists, public health authorities, and those involved in every facet of the policymaking and legislative processes.

As has been discussed, industry has not hesitated to attack state based tobacco control organisations. There is no reason to believe the tactics used against $\mathrm{COSH}$ will not be used against similar organisations at either the national or local level.

Industry also sought to undermine the region's primary coalition, APACT. Industry's track record of interfering in both World Conferences on Smoking or Health and APACT conferences must send a note of caution to future APACT conference planners and participants. Industry is likely to adopt and expand those strategies that were successful for there is no reason to suppose the industry will pay less attention to these conferences in the future.

In documenting industry's involvement in subverting the work of WHO, the review committee concluded industry's actions were "unacceptable and must be condemned". ${ }^{81}$ Similarly, industry's activities throughout Asia were unacceptable and their strategies and tactics must also be condemned. The actions documented in this paper undoubtedly slowed and undermined effective tobacco control throughout Asia. Thwarting attempts to introduce legislation and other effective tobacco control measures put millions of smokers at risk of contracting tobacco related diseases.

\section{ACKNOWLEDGEMENTS}

The authors wish to thank Ms Fiona Byrne, information manager for the Australian and Asian tobacco documents project, for her ready assistance in document location; Ms Mary Assunta for her insightful comments on the topic; and the reviewers for their helpful feedback.

\footnotetext{
Authors' affiliations

J Knight, S Chapman, School of Public Health, University of Sydney, Sydney, NSW, Australia

Funding source: National Health \& Medical Research Council (Australia) \#153857; National Institutes of Health (USA) \#1 R01 CA871 10-01A1
} 


\section{REFERENCES}

1 Donck P. Centre d'Information et de Documentation. "Our Opponents": [speech given at INMAC Conference, Amsterdam]. 12 Oct 1992. Philip Morris. Bates No. 2028351932/1952. http://legacy.library.ucsf.edu/tid/ yif56e00.

2 Tully R. Tobacco Documentation Centre. [Fax to David Bacon forwarding a paper on the activist movement and a presentation on anti-tobacco strategies] 2 Dec 1993. British American Tobacco. Bates No. 503143031/3057. http:// tobaccodocuments.org/health_canada/R1676.html [Accessed 29 Jun 2004].

3 Virendra S. Background to the structure and operations of the activist movement. 15 Nov 1994. Philip Morris. Bates No. 2501110753/0775. http://legacy.library.ucsf.edu/tid/ynh22e00.

4 INFOTAB. Report on the strategy of activists and how to respond to that strategy. 22 Sep 1982. Philip Morris. Bates No. 2501021445/1451. http:// legacy.library.ucsf.edu/tid/msv32e00

5 Philip Morris International. Global regulatory network: "we will be legal everywhere we do business". 1993. Philip Morris. Bates No. 2025599767/ 9875. http://legacy.library.ucsf.edu/tid/cij35e00.

6 American Cancer Society. Trade for life: global plan. Apr 1990. R.J. Reynolds. Bates No. 51 1993068/3092. http://legacy.library.ucsf.edu/tid/ rti43d00.

7 Tully R. INFOTAB. Personalities and organisations - 8th WCTH: [author is inferred - material for briefing session for conference monitors]. 1992. Philip Morris. Bates No. 2500121045/1048. http://legacy.library.ucsf.edu/tid/ $\mathrm{nxk} 19 \mathrm{e} 00$.

8 Philip Morris International. The international anti-smoking movement: organizations and individuals (Part I). Jun 1986. Philip Morris. Bates No. 2023264959/5009. http://legacy.library.ucsf.edu/tid/cks02a00

9 Philip Morris Asia Inc. Corporate affairs plan: 1990-1992. Dec 1989. Philip Morris. Bates No. 2500084000/4042. http://legacy.library.ucsf.edu/tid/ lil19e00.

10 Hill and Knowlton. Philip Morris in Asia: challenges and opportunities. Feb 1993. Philip Morris. Bates No. 2504065729/5748. http:// legacy.library.ucsf.edu/tid/eiw19e00

11 Wehrfritz G. Crusaders: Marlboro's Asian nightmare. Newsweek 20 Jun 1994. Philip Morris. Bates No. 2050154339A. http:// legacy.library.ucsf.edu/tid//rh82e00.

12 British American Tobacco Co. (HK) Limited. Cigarette smoking and health: [issues briefing paper]. May 1982. British American Tobacco (Non MSA) $\mathrm{http}: / /$ tobacco.health.usyd.edu.au/tds/BAT_MIS_00001 [Accessed 29 Jun 2004].

13 Stein Associates Inc. Hong Kong: key government personalities in tobacco. 10 Dec 1983. Brown \& Williamson. Bates No. 501104006/4011. http:// legacy.library.ucsf.edu/tid/mwf23foo

14 Albert D. Your request: [memo to J. Robinson]. 12 Apr 1994. R.J. Reynolds. Bates No. 512051448/1449. http://legacy.library.ucsf.edu/tid/hbg43d00.

15 Trairatanobhas V. Minutes of meeting: [memo to C. Duffy]. 1 Mar 1993. British American Tobacco. Bates No. 300537165. http:// tobacco.health.usyd.edu.au/tds/BAT300537165 [Accessed 29 Jun 2004].

16 Corner RM. Philip Morris Europe. Countermeasures development program: [speech given at ICOSI meeting, Zurich]. 23 May 1979. Tobacco Institute. Bates No. TIMN0156508/6520. http://legacy.library.ucsf.edu/tid/ let82f0o.

17 Philip Morris Asia Inc. [Corporate affairs - regional overview: Asia]. 1995. Philip Morris. Bates No. 2051824808/4824. http://legacy.library.ucsf.edu/ $\mathrm{tid} /$ luvl $4 \mathrm{c} 00$

18 British American Tobacco. Key area paper - corporate affairs. 15 Mar 1993. British American Tobacco. Bates No. 501575478/5488. http:// tobaccodocuments.org/bc moh/30826.html [Accessed 29 Jun 2004].

19 Mostyn J. [Overview of anti-smoking groups activities and the tobacco industry's response]. 23 Apr 1981. British American Tobacco. Bates No. 109877230/7237. http://www.library.ucsf.edu/tobacco/batco/html/ $8200 / 8265$ [Accessed 29 Jun 2004].

20 Anon. Hong Kong: update on anti-smoking campaign \& Consumer Councilprogram and personalities. 7 Dec 1983. Brown \& Williamson. Bates No. 501 104026/4031. http://legacy.library.ucsf.edu/tid/nwf23f00.

21 Valdez G. INFOTAB. Smoking control in south-east Asia. 6 Dec 1983. Brown \& Williamson. Bates No. 699101435/1437. http://legacy.library.ucsf.edu/ $\mathrm{tid} / \mathrm{iio} 01 \mathrm{f00}$.

22 Winokur $M$. The activist movement: [attachment to memo from $M$ Winokur to PM executives]. Oct 1992. Philip Morris. Bates No. 2025497597/7610. http://legacy.library.ucsf.edu/tid/hlz88e00.

23 Donner RK. Strategy of the antis for Taiwan: [attachment to fax from RK Donner to RJR executives]. 10 Jan 1992. R.J. Reynolds. Bates No. 515011050/1052. http://legacy.library.ucsf.edu/tid/plg03d00.

24 Virendra S. Changes in the activist movement: [attachment to memo from S Virendra]. 27 Sep 1994. Philip Morris. Bates No. $2501110749 / 0751$. http://legacy.library.ucsf.edu/tid/kck49e00

25 Philip Morris Asia Inc. APACT. Jan 1993. Philip Morris. Bates No. 2500080700/0703. http://legacy.library.ucsf.edu/tid/wrl19e00

26 Suber RL, Rees C. Notes on WHO anti-tobacco program from a literature search done on 1/7/93. 7 Jan 1993. R.J. Reynolds. Bates No. 508303977/ 3978. http://legacy.library.ucsf.edu/tid/dow93d00.

27 INFOTAB. World action: a guide for dealing with anti-tobacco pressure groups. Oct 1989. Philip Morris. Bates No. 2504063806/3817. http:// legacy.library.ucsf.edu/tid/izv19e00

28 Suk-Woo Y. Report on activities implementing 1990-1994 action plan on tobacco or health - Republic of Korea: presented at 3rd Working Group on TOH, Manila, Philippines. 5 Apr 1994. Philip Morris. Bates No. 2048551152. http://legacy.library.ucsf.edu/tid/wso72e00.
29 Mackay J. State of Dr Judith M Mackay on behalf of the Asian Consultancy on Tobacco Control before the House Committee on Energy and Commerce, Subcommittee on Health and the Environment: hearing on strategies by US tobacco companies in the developing world. 17 May 1990. Lorillard. Bates No. 87649792/9810. http://legacy.library.ucsf.edu/tid/gdk98c00.

30 R.J. Reynolds International. RJRI news report. 20 Nov 1996. R.J. Reynolds. Bates No. 522603729/3764. http://legacy.library.ucsf.edu/tid/lxc50d00.

31 World Health Organization. A suggested model of a Tobacco Product Control Law: [Annex 7 in Report working group on tobacco or health]. Apr 1994. Philip Morris. Bates No. 2048551 163/1169. http://legacy.library.ucsf.edu/ $\mathrm{tid} / \mathrm{zso} 2 \mathrm{e} 00$.

32 Chapman S. The lung goodbye: a manual of tactics for counteracting the tobacco industry in the 1980s. Consumer Interpol, 1983.

33 Dollisson J. 1989 2nd revised forecast presentation - corporate affairs. 15 Jun 1989. Philip Morris. Bates No. 2500101311/1323. http:// legacy.library.ucsf.edu/tid/fml19e00.

34 Philip Morris International. The international anti-smoking movement: organisations and individuals (Part II). Jun 1986. Philip Morris. Bates No. 2023265010/5063. http://legacy.library.ucsf.edu/tid/ujs02a00

35 Bloxcidge J. INFOTAB. Asia anti-smoking networks: [forwarding a copy of "Anti-smoking organizations, the Asia network"]. 6 Sep 1989. British American Tobacco. Bates No. 304002757/2764. http:// tobacco.health.usyd.edu.au/tds/BAT304002757_2764 [Accessed 29 Jun 2004].

36 Anon. Anti-smoking organizations. 1992. R.J. Reynolds. Bates No. 512565784/5865. http://legacy.library.ucsf.edu/tid/hbk33d00.

37 Anon. Advocacy organizations and individuals. 1995. Philip Morris. Bates No. 2046318100/8124. http://legacy.library.ucsf.edu/tid/yrq42e00.

38 Moskowitz S. R.J. Reynolds issues guide. 6 Nov 1996. R.J. Reynolds. Bates No. 520340962/1200. http://legacy.library.ucsf.edu/tid/ycl66d00.

39 Lenling A. List of tobacco control advocates: [attachment to memo from A Lenling to M Winokur]. 24 Sep 1999. Philip Morris. Bates No. 2081380266/ 273. http://legacy.library.ucsf.edu/tid/ykw65c00.

40 Goddard C. Philip Morris Asia Inc. [Inter-office memo forwarding antitobacco documents]. 8 Dec 1994. Philip Morris. Bates No. 2048551059 http://legacy.library.ucsf.edu/tid/kkq36e00.

41 Winokur M. WHO regional plan for Asia. 17 Jan 1995. Philip Morris. Bates No. 2048551082. http://legacy.library.ucsf.edu/tid/qso72e00.

42 Mackay J. The politics of tobacco. Hong Kong Med J 1998;4:41 1-14.

43 Brady B. Unofficial minutes of Asia Pacific industry affairs meeting. 23 Aug 1994. British American Tobacco. Bates No. 502592934/2936. hitp:// tobacco.health.usyd.edu.au/tds/BAT502592934_2936 [Accessed 29 Jun 2004].

44 Philip Morris International. The perspective of PM International on smoking and health issues. 27 Mar 1985. Philip Morris. Bates No. 2023268351/ 8364. http://legacy.library.ucsf.edu/tid/tus98e00.

45 Philip Morris. EFTA Eastern Europe Middle East Africa. Long range plan 1990-1992. Dec 1989. Philip Morris. Bates No. 2500066142/6294. http:// legacy.library.ucsf.edu/tid/bhr02a00

46 Murray W. Remarks by William Murray, Vice Chairman of the Board, Philip Morris Companies Inc. at the 1989 Philip Morris Legal Conference, RitzCarlton Hotel, Florida. 4 Apr 1989. Philip Morris. Bates No. 2023265282/ 5295. http://legacy.library.ucsf.edu/tid/qpi46e00

47 Tobacco Industry (Hong Kong). Some suggestions for the industry's approach on the smoking health issue. Feb 1973. Philip Morris. Bates No. 2073422442/2446. http://legacy.library.ucsf.edu/tid/lif95c00

48 Chantornvong S, McCargo D. Political economy of tobacco control in Thailand. Tobacco Control 2001;10:48-54.

49 Julie Russell \& Associates Ltd, Tony Turner \& Associates Ltd. [Extracts from a public relations proposal prepared for the Tobacco Institute of Hong Kong in May 1987 and tabled at the 69th meeting of directors]. $17 \mathrm{Feb}$ 1989. Philip Morris. Bates No. 2504002842/2843. hitp://legacy.library.ucsf.edu/tid/ zfw $19 \mathrm{e} 00$

50 Ward ME. Trip to Hong Kong publicizing ETS survey results. 5 Jul 1988. R.J. Reynolds. Bates No. 517587271/7272. http://legacy.library.ucsf.edu/tid/ zor31d00.

51 Winokur M. [Memo to A Whist re: Council on Smoking and Health]. 29 Jun 1987. Philip Morris. Bates No. 2504046630. http://legacy.library.ucsf.edu/ $\mathrm{tid} / \mathrm{mk} \times 32 \mathrm{e} 00$

52 Winokur M. [Memo to YY Tang re: Council on Smoking and Health]. 23 Dec 1987. Philip Morris. Bates No. 2504046626. http://legacy.library.ucsf.edu/ $\mathrm{tid} / \mathrm{bdv} 19 \mathrm{e} 00$.

53 Tobacco Institute of Hong Kong Limited. SRH smoking survey shows overwhelming support for status quo on smoking and cigarette advertising. 10 Jun 1988. Philip Morris. Bates No. 2504002557/2562. http:// legacy.library.ucsf.edu/tid/oiw32e00

54 Tobacco Institute of Hong Kong Limited. Response to anti-smoking proposals made by the Hong Kong Council on Smoking and Health. Jun 1989. Philip Morris. Bates No. 2504064365/4380. http://legacy.library.ucsf.edu/tid/ ohw32e00

55 Tobacco Institute of Hong Kong Limited. Critique by Tobacco Institute of Hong Kong on Hong Kong Council on Smoking and Health (COSH) recommendations. Jun 1989. Philip Morris. Bates No. 2504064381/4386. http://legacy.library.ucsf.edu/tid/phw32e00.

56 Turner AD. Asian Tobacco Council Limited. Child smokers - Hong Kong. $9 \mathrm{Jul}$ 1991. Philip Morris. Bates No. 2504002949. http://legacy.library.ucsf.edu/ $\mathrm{tid} / \mathrm{jkw} 19 \mathrm{e} 00$.

57 Tobacco Institute of Hong Kong Limited. Overall working report on consultation paper for COSH proposals: [paper for agenda item 3 of 73rd meeting of directors]. Jul 1989. Philip Morris. Bates No. 2504002814/2819. http://legacy.library.ucsf.edu/tid/fgw19e00. 
58 Rekart P. Asian Tobacco Council basic charter: [attachment to memo re: Corporate Affairs meeting]. Dec 1989. Philip Morris. Bates No. 2504042080/2081. http://legacy.library.ucsf.edu/tid/xaw32e00

59 Fletcher RJ. Rothmans (Far East) Limited. Job description. 13 Feb 1990. British American Tobacco. Bates No. 304002746/2749. http:// tobaccodocuments.org/guildford_misc/304002746-2749.html [Accessed 6 May 2003].

60 Turner AD. Asian Tobacco Council. November public affairs conference: Hong Kong, November 19. 13 Jun 1991. Philip Morris. Bates No. 2504002954/2959. http://legacy.library.ucsf.edu/tid/fkw19e00

61 Donner RK. Draft press release: [attachment to fax from R Donner re: Taiwan] 11 Jan 1992. R.J. Reynolds. Bates No. $515011053 / 1055$. http:// legacy.library.ucsf.edu/tid/qlg03d00.

62 Rupp JP. Covington \& Burling. [Letter to Dr Sharon Boyse]. 12 Mar 1992 Lorillard. Bates No. 87602277/2281. http://legacy.library.ucsf.edu/tid/ bmll 1e00.

63 Philip Morris Asia/Pacific. Three year plan 1993-1995. Dec 1992. Philip Morris. Bates No. 2051824318/4332. http://legacy.library.ucsf.edu/tid/ uqc06e00

64 Japan Tobacco. Action plan for APACT. 1 Mar 1993. Philip Morris. Bates No. 2500054003. http://legacy.library.ucsf.edu/tid/qpi19e00.

65 Tobacco Institute of Japan. Action plan for APACT meeting. 1 Mar 1993 Philip Morris. Bates No. 2500054004. http://legacy.library.ucsf.edu/tid/ rpil9e00.

66 Tobacco Institute of Japan. Monitor for APACT. 1 Apr 1993. Philip Morris. Bates No. 2500054005. http://legacy.library.ucsf.edu/tid/spi19e00.

67 Dollisson J, Donner RK. US Cigarette Export Association. Press release: US companies defend cigarette exports. 12 Jun 1989. Philip Morris. Bates No. 2500080767/0770. http://legacy.library.ucsf.edu/tid/xvc42e00

68 Fung J. Asian Pacific Conference on Cigarette Smoking \& Health. 12 Jun 1989. Philip Morris. Bates No. 2500080712 . http://legacy.library.ucsf.edu/ $\mathrm{tid} / \mathrm{dvc} 42 \mathrm{e} 00$

$69 \mathrm{Ng} \mathrm{R}$. Corporate Affairs weekly highlights: week ending August 30, 1991. 3 Sep 1991. Philip Morris. Bates No. 2504038185/887. http:// legacy.library.ucsf.edu/tid/llu19e00.

70 Telling WL. Tobacco Institute of Japan. With regard to third APACT conference. Apr 1993. Philip Morris. Bates No. 2500054001/4002. http:// legacy.library.ucsf.edu/tid/kjf42e00.
71 Harris D. [Memo to M Winokur]. 29 Apr 1993. Philip Morris. Bates No. 2500054006/4008. http://legacy.library.ucsf.edu/tid/tpi19e00.

72 Philip Morris Asia Inc. 1995 APACT conference Chiang Mai, Thailand Nov 22-24, 1995: report 1. 23 Nov 1995. Philip Morris. Bates No. 2046304013/4014. http://legacy.library.ucsf.edu/tid/klf97d00.

73 Philip Morris Asia Inc. 1995 APACT conference Chiang Mai, Thailand Nov 22-24, 1995: report 2. 24 Nov 1995. Philip Morris. Bates No. 2046304015/4020. http://legacy.library.ucsf.edu/tid/llf97d00.

74 Philip Morris Asia Inc. 1995 APACT conference Chiang Mai, Thailand Nov 22-24, 1995: report 3 (part one). 28 Nov 1995. Philip Morris. Bates No. 2046304032/4040. http://legacy.library.ucsf.edu/tid/zkf97d00

75 Philip Morris Asia Inc. 1995 APACT conference Chiang Mai, Thailand Nov 22-24, 1995: report 3 (part two). 28 Nov 1995. Philip Morris. Bates No. 2046304041/4047. http://legacy.library.ucsf.edu/tid/alf97d00.

76 Philip Morris Asia Inc. 1995 APACT conference Chiang Mai, Thailand Nov 22-24, 1995: report 3 (part three). 28 Nov 1995. Philip Morris. Bates No. 2046304048. http://legacy.library.ucsf.edu/tid/blf97d00.

77 Goddard C. Corporate Affairs review. 1997. Philip Morris. Bates No. 2074188961/9005. http://legacy.library.ucsf.edu/tid/ojk45c00.

78 Turner C. Asian Tobacco Council. Tobacco: the battle for social acceptance, the sixth World Tobacco Exhibition \& Symposium. 25 Oct 1990. R.J. Reynolds. Bates No. 511970081/0100. http://legacy.library.ucsf.edu/tid/ mfk43d00.

79 Kornegay HR. Worldwide smoking \& health developments. 30 Sep 1985. Tobacco Institute. Bates No. TIMNO216125/6143. http:// legacy.library.ucsf.edu/tid/qml72fo0.

80 Dollisson J. "Corporate Affairs": [speech given at PMI Marketing Conference, Florida]. 21 Jun 1990. Philip Morris. Bates No. 2500120138/0153. http:// legacy.library.ucsf.edu/tid/nzd42e00.

81 Committee of Experts on Tobacco Industry Documents. Tobacco company strategies to undermine tobacco control activities at the World Health Organization. Geneva: World Health Organization, 2000 http://www.who.int/tobacco/en/who_inquiry.pdf [Accessed 30 Jun 2004].

82 Muggli M, Hurt R. Tobacco industry strategies to undermine the 8th World Conference on Tobacco or Health. Tobacco Control 2003; 12:195-202. 